boundaries which contained a number of the solid fission product elements. Mr. Lambert reported on the irradiation behaviour of uranium dioxide particles in cermets at burn-ups in the range 5-12 per cent and was mainly concerned with the swelling which appeared to proceed eventually at an inexorable rate of about 1.7 volume per cent per 1 per cent of burn-up.

Detailed investigations of the behaviour of krypton gas bubbles introduced by ion bombardment in uranium dioxide using the electron microscope were described by G. H. Bannister, R. M. Cornell and B. M. Jeffrey (Central Electricity Generating Board, Berkeley).

There were more papers dealing with the irradiation behaviour of non-fissile ceramics than with any other single topic. Both gas release and dimensional stability were, as were fissile oxides, major topics for consideration. In-pile release of helium from beryllia had been investigated by Y. Carteret, J. Bareau and J. Elston (Commissariat à l'Énergie Atomique, Saclay), who showed that after a few hundred hours the release of helium attained a constant level. Measurements of the diffusional release of tritium from beryllia by fast neutron annealing had been made by K. T. Scott and L. L. Wassell (Atomic Energy Research Establishment, Harwell). The behaviour exhibited, namely, that of initial bursts followed by steady-state release, was very similar to that of inert gas in fissile oxides. Activation energies varied from 48 to $59 \mathrm{kcal} /$ mole. Investigations of the nature of fast neutron-induced defects in single crystal alumina and in polycrystalline alumina and magnesia, using transmission electron microscopy, changes in lattice parameter, density and length were reported by R. S. Wilks et al. (Atomic Energy, Harwell), by M. Stevanovic and J. Elston (Commissariat à l'Énergie Atomique, Saclay) and by R. P. Thorn and V. C.
Howard (Reactor Materials Laboratory, Culcheth). A still more sophisticated technique for studying irradiationinduced defects by the scattering of long wave-length neutrons was reported by D. G. Martin (Atomic Energy Research Establishment, Harwell), who showed that the smaller clusters often visible under the electron microscope as irresolvable dots probably contained less than thirty defects per cluster. The overall situation on irradiation effects in ceramic oxides was well summarized in a paper by B. S. Hickman and D. G. Walker, who discussed at some length correlations between the irradiation behaviour of beryllia, alumina and magnesia as well as zine oxide. The irradiation behaviour of only one nonfissile carbide, namely, polycrystalline, self-bonded, porous, cubic, silicon carbide, was discussed by R. P. Thorn, V. C. Howard and B. Hope (Reactor Materials Laboratory, Culcheth) in terms of dimensional change and $\mathrm{X}$-ray parameter measurements. The saturation growth obtained was, as is normal, a function of temperature and was paralleled by saturation effects in thermal conduc. tivity. There was, however, an appreciably slower recovery on annealing of thermal conductivity compared with dimensions.

The meeting was organized by Dr. D. T. Livey of the Metallurgy Division, Atomic Energy Research Establish. ment, Harwell, and, as was apparent, received a considerable amount of international support. It was attended by 152 people and, as has now become the well-established form with the Basic Science Section meetings, approximately half were members of the Society and half were guests. The papers presented at this meeting will be published as a separate volume of the proceedings of the British Ceramic Society.

\section{J. Williams}

\title{
REVIEW OF THE FOSSIL RECORD
}

A SYMPOSIUM entitled "A Review of the Fossil A Record", organized jointly by the Geological Society of London and the Palaeontological Association, was held at the University College of Swansea during December 20-21, by invitation of Prof. F. H. T. Rhodes, head of the Department of Geology. It was attended by some 160 members.

The meeting had been arranged in order to discuss a projected publication volume by the Geological Society, and in this respect it followed the pattern of the symposium on the Phanerozoic time-scale held at Glasgow in February 1964. The volume in preparation is to consist mainly of contributions by more than a hundred specialists, covering the whole fossil record, both plants and animals, organized into thirty chapters on a systematic basis. Each contributor was asked to recommend a classification of his allotted taxa, and to document the first and last reported fossil occurrence of each taxon. To do this thoroughly was thought to be a sufficient task, and it carried the implication that there was continuity of life between these first and last occurrences, even if no intermediate record had yet come to light. Thus, a survey of the ranges of taxa covering all fossils through geological time could be included in a single volume. It was left to the contributor in each case to decide on the degree of taxonomic sub-division; so in some cases familics and genera, and in others, super-families or orders, have been recorded. In this way some idea of the diversification can be given, without departing from the minimum requirement for first and last documented records.

An editorial committee shared the systematic editing and maintained contact with specialist contributors. 'The committee also worked out a standard stratigraphical scale, so that data could be presented in a uniform way. To this end, questionnaires were first sent out, and after some discussion a scale was agreed on, admittedly arbitrary and temporary, for the use of the symposium only. However, some longer-term benefit may result from this, for although the scale was divided into units of about stage rank and did not attempt any tidy or final codifying of these units, the committee did nevertheless define the base of each selected unit reasonably precisely and unambiguously. This project demonstrated the need for a standard global stratigraphical scale, and illustrated tho principle of defining units by single reference horizons at their bases. The degree of division of the stratigraphical scale was a compromise, being on the one hand too fine for much international correlation, and on the other too coarse to plot some precisely known records. The stratigraphical scale was used for a series of charts on which the ranges of taxa were plotted as lines joining first and last records. Some precision was also lost because presence only, and not position, within each division was plotted. These working charts were on display at Swansea, and will be re-drawn for publication in the fortheoming volume.

The object of the symposium meeting was to discuss issues relevant to this compilation. Eight main papers and several short prepared contributions were presented and will appear, with some of the discussion, in the symposium volume.

The symposium was introduced with a review of the origin and development of Pre-Cambrian life and the base of the Cambrian system by J. W. Cowie. Speculation on the origin of life on this planet, as related to hypotheses of the composition and state of the hydrosphere and atmosphere, was briefly surveyed, and was followed by a review of the earliest organized structures in rocks. Mention was made of the recent discovery by Barghoorn of organized carbon residues about $3,000 \mathrm{~m} . \mathrm{y}$. old, possibly 
older than the better-known stromatolitic dolomite of McGregor from Bulawayo which has been dated only by correlation with distant rocks via 2,700 -m.y.-old granite In rocks less than 2,000 m.y. old, stromatolitic, algal and acritarchal structures are common. The first faunas so far established may not be much older than established Cambrian; how much older they are raises the question of the biostratigraphic definition of the base of the Cambrian. The distinct and now well-known Ediocara fauna is only marginally older than archaeocyathid or trilobitebearing Cambrian. Thus, shelled brachiopods could be the oldest animal fossils yet known, the newly discovered obolids from arctic Canada having been uncertainly argued, from radiometric evidence, to be about $700 \mathrm{~m} . \mathrm{y}$. old. The degree of ( ? explosive) evolution of the known Lower Cambrian fauna was then examined in relation to various hypotheses.

In discussion, it was pointed out by P. C. SylvesterBradley that a distinction should be made between complex organic chemicals preserved in ancient rocks, which might be abiogenic, and relics of organized life. It was argued by R. Goldring that trace fossils (except, for example, burrows) were commonly formed at the sediment-water interface, which itself might not be generally preserved. This would account for the discrepancy between ranges of fossils and traces of presumed similar animals. Even so, thore was a marked increase in traces of biological activity with the appearance of trilobites.

A computer analysis of the fossil record was presented by B. M. Funnell and J. L. Cutbill. The committee had decided that the large amount of data to be assembled according to a common pattern justified some attempt at computer analysis. It was only possible to report at the meeting results based on the unedited charts already submitted; however, 1,566 taxa from these were used, and it seemed unlikely that later submissions would alter the results in any substantial way. Taxonomic rank depends perhaps as much on the history of palaeontological investigations as on any biological hierarchy, and therefore no particular attempt was made to correct according to their systematic rank the taxa which had been selected by contributors, except that in three cases where large numbers of families had been documented in a limited part of the stratigraphical column these were reduced to super-families. Errors affecting the ranges of taxa were inevitable, not only because of the many limitations of the fossil record, but also as the result of the systematic attribution of fossils and the history and geography of palaeontological research. A significant bias was inevitably introduced by the fact that living representatives of taxa, rather than fossils, had been documented for the latest stratigraphical unit, thus heavily over-weighting this latest interval by comparison with all other intervals, which depended solely on the fossil record. For analyses of ranges standard units were taken as equal, although many were known geochronologically to be unequal, and others were not sufficiently known. The known units averaged about 5-6 m.y. back to the Triassic, and 5-10 m.y. back to the Devonian, increasing to 15 or even $30 \mathrm{~m} . \mathrm{y}$. for the early Palaeozoic ages. The authors were under no illusions about the limitations of what could be obtained by numerical abstracting and presentation of the data (for example, in histograms, with successive smoothing), but nevertheless it was possible to draw some general conclusions from the tabulations presented. Frequencies of all taxa, initial or final records per stratal unit with major taxa taken separately or totalled, were not random; some trends were noticeable, reflecting rapid diversification in early Palaeozoic time and a distinct Palaeozoic mode, with a marked 'low' in the curves at about the Permian/Triassic boundary. The Mesozoic/Cenozoic boundary was not so distinctly marked.

Lower Palaeozoic appearances were discussed by M. R. House, who first commented on what the computer analyses had shown independently, namely, the genius of John Phillips 125 years ago in distinguishing the broad Palaeozoic, Mesozoic and Cenozoic divisions of life. House surveyed the progress and diversification of most major taxa through Palaeozoic time. In assessing claims for an evolutionary explosion it would be important to distinguish between taxonomic diversification and the numerical abundance of individuals within each taxon. However, an initial multiplication of genera to a high early maximum was followed by a slower decline. Moreover, early diversification was more rapid in higher ranks of taxa. Although rocks of Cambrian age have yielded records of most phyla, the Ordovician might well prove to be the time of most marked explosion and proliferation. The detailed pattern was probably controlled ecologically, and might have been markedly affected by the feeaing habits of different groups.

By reference to the Dalmanellacea, V. G. Walmsley showed how relatively minor and continuous taxonomic revision could produce major changes in range charts. But, as pointed out by B. M. Funnell, when many records are combined small changes will be self-cancelling and so will not seriously affect the kind of statistical study conducted.

Permo-Triassic changes were discussed in a paper by F. H. T. Rhodes (read by M. J. S. Rudwick), who argued first that the Permian was a time of rich and diversified faunas, even those that were shortly to become extinct; thus there was little prior indication of impending changes. Although substantial extinctions took place towards the end of Permian time, the noticeable effect was due to many gaps not being immediately filled, so that early Triassic faunas lacked variety and contrast. Certainly, although none of the many hypotheses for these changes has yet been substantiated, and few continuous marine successions across the boundary are known, the marked change in the fossil record does not appear to be an artefact and demands explanation.

Triassic/Jurassic vertebrate changes were discussed by C. B. Cox, who showed that the most fundamental changes on land took place in Triassic time, though correlation of some of the continental strata is uncertain. Extensive adaptation to marine conditions was a distinctive feature of Triassic time. This pattern gave some coherence to the Mesozoic era so far as vertebrates were concerned.

Cretaceous-Tertiary marine faunal changes were discussed by J. M. Hancock, who limited himself to a careful study of the commonly accepted dramatic extinction of ammonites and possible continuation of belemnites. Decline was already evident in Campanian time and, indeed, gradual extinction was also taking place in Maestrichtian time, although world-wide regression at the close of Maestrichtian time obscured the record. Many important occurrences have been recorded recently from Danian and Upper Palaeocene rocks so that changes, while gradual in detail, were yet distinctive when viewed on a sufficiently broad scale.

G. M. Phillip commented on the record of the Echinoids, which evolved slowly through Ordovician to Triassic time, with about one new family per period, and then dramatically diversified in Lower Lias time, with new families continuing to appear at about 15 times that rate to the present day.

Plant-insect relationships were next discussed. The apparent dramatic changes in the insect record are largely attributed to the relatively few rich fossil insect horizons, but some established stages of insect evolution were nevertheless outlined by J. M. Smart. A number of suggestions were made by $\mathrm{N}$. F. Hughes about plant evolution and its possible relationship to insect development. Most insects depend directly on plants for food, and the suggested later Cretaceous development of angiosperms may not have had much impact on insect evolution because the pre-angiosperms (pteridophytes and gymno- 
sperms) provided a similar habitat when equatorial. A critical stage may have been reached with the emergence of tall land plants in Devonian time; insects would have crawled up these plants and developed flight. The im. portant diversification of reproductive structures in plants in early Carboniferous time was probably a protective response to attack by insects, which themselves became adapted in diverse manners. Insect pollination could have begun in Permian time.

The last principal contribution, biochemical evolution and the fossil record, by L. B. Tarlo, reviewed a rapidly expanding field of investigation, largely consequent on recently developed techniques using amino-acid analysis. Comparative biochemistry has long provided some independent taxonomic criteria, but only recently has the systematic investigation of the biochemical record of the rocks been stimulated by the possibilities of protein taxonomy. With what reliability particular combinations of amino-acids may be used to infer the presence of, for example, collagen is still uncertain, but this line of investigation promises well. It is complicated by the dissovery that not only do many fossils yield rich biochemical results, but so do their enclosing rocks; hence the source of any particular compound is often difficult to determine.

A. Hallam, from studies of strontium/calcium ratios in cephalopod shells, suggested that later Palaeozoic nautiloids may be related to more 'primitive' forms than goniatites.

Throughout the discussion the basic questions of evolutionary cause and effect recurred, often inconclusively. Linguistic care was necessary to avoid 'loaded' descriptions such as one form 'ousting' another from its 'ecological niche'. But not all was negative. Some correlation between changes due to physical environment and those due to selective pressure for evolutionary adaptation seemed reasonable. If this were pressed in terms of what is becoming known about the inevitable interplay of tectonic, eustatic, gradational and climatic changes, for example, then the evident rate of biological change may be partly explicable.

It is hoped that the whole symposium and volume will. stimulate palaeontologists and others to extend this study to progressively lower levels of taxa as a contribution to the record of evolution of the biosphere as a whole.

W. B. HaRLAND

\section{CALEDONIAN MAGMATISM IN NORTH WALES}

\author{
By J. E. THOMAS \\ Sedimentology Research Laboratory, Department \\ of Geology, University of Reading
}

\author{
M. H. DODSON* and D. C. REX \\ Department of Geology and Mineralogy, \\ University of Oxford
}

\section{G. FERRARA}

Nuclear Geology Laboratory, University of Pisa, Italy

$I^{N}$ $\mathrm{N}$ a survey of the British Caledonides, $\operatorname{Read}^{1}$ emphasized the need for more information on the many aspects of Caledonian magmatism in Britain. He briefly discussed the few available isotopic ages for the Caledonian granites of the 'metamorphic' and 'non-metamorphic' belts, but pointed out that further determinations were clearly required. More recently, Fitch et $a l .{ }^{2}$ have published geochronological data relating to magmatic activity within the 'non-motamorphic Caledonides' of North Wales, and have reviewed aspects of Caledonian orogeny and metamorphism in Britain ${ }^{3,4}$. This article reports the results of isotopic age determinations on biotites from hornfelses associated with the Tan-y-grisiau 'microgranite', Ffestiniog, North Wales, and briefly discusses their significance in investigations of Caledonian magmatism.

Several authors ${ }^{5-10}$ have made reference to the Tan-ygrisiau intrusion, but little detailed work has been published concerning its petrology, form and age. Recently, one of us (J. E. T.) has made a petrological and petrochemical examination of the intrusion and its aureole. During this work biotite-bearing motamorphic rocks were collected from the south-east margin of the intrusion (350 yd. west of Brynmelyn cottage, SH687430) which have since proved suitable for age determinations by the potassium-argon and the rubidium-strontium methods. Tho samples are representative of two rock types: a biotite-rich contact hornfols and a biotite-bearing xenolithic rock included in granite veins penetrating the country rock. Biotites in the granite itself were examined in thin-section but were found to be extensively chloritized and unsuitable for age determinations. The dating of an intrusion solely by means of measurements on associated hornfelses does not appear to have been reported previously, although Erickson and Kulp ${ }^{11}$ and Hurley et al. ${ }^{12}$ have given data for fine-grained hornfelses, which agreed well with rosults from associated igneous mica. Whole-rock determinations on the granite itsolf are in hand.

* Present address: Department of Geology, University of Leeds.
Potassium-argon determinations were made at Oxford, where a Franz isodynamic separator was used for minoral separation. Argon was determined on a Reynolds mass spectrometer using an isotope dilution technique with argon-38 tracer. Potassium was determined by flame photometry. The analytical precision for both elements is estimated as \pm 2 per cent from replicate determinations. The uncertainties in the ages given in Table 1 are based on this figure, giving a precision of \pm 3 per cent in the $\mathrm{Ar} / \mathrm{K}$ ratio. The rubidium-strontium determinations were done at Pisa. The biotite sample used for the deter. mination on the contact hornfels was taken from a separation done at Oxford, part of which had already been used for duplicato potassium-argon determinations. The xenolithic biotite was separated at Pisa using a Franz separator. A selected sample was further purified by grinding under alcohol and resieving. The rubidium and strontium contents of the biotite wore determined by an isotope dilution method using an Atlas $\mathrm{CH} 4$ mass spectrometer with normal colloctor. The analytical results are given in Table 2.

The 'uncorrected ages' in Table 2 are based on an assumed normal ${ }^{87} \mathrm{Sr} /{ }^{86} \mathrm{Sr}$ ratio of 0.712 at the time of metamorphism. Because of the difference between these and potassium-argon ages, it was decided to make some "whole-

\begin{tabular}{|c|c|c|c|c|}
\hline $\begin{array}{c}\text { Sample No. and } \\
\text { description }\end{array}$ & $\underset{\text { (per cent) }}{\mathbf{K}}$ & $\stackrel{40 \mathrm{Ar}}{\text { (p.p.m.) }}$ & $\frac{\text { Atm, Ar }}{\text { Total Ar }}$ & Age (m.y. \\
\hline $\begin{array}{l}J E T / 1 \\
\text { Contact- } \\
\text { hornfels } \\
\text { (biotite) }\end{array}$ & $\begin{array}{l}5 \cdot 54 \\
5 \cdot 54\end{array}$ & $\begin{array}{l}0 \cdot 117 \\
0 \cdot 180\end{array}$ & $\begin{array}{l}4 \cdot 6 \\
3 \cdot 3 \quad \text { mean }\end{array}$ & $\begin{array}{l}398 \pm 11 \\
409 \pm 11 \\
404 \pm 8\end{array}$ \\
\hline $\begin{array}{l}J E T / 2 \\
\text { Xenolith } \\
\text { (biotite) }\end{array}$ & $5 \cdot 58$ & $0 \cdot 183(5)$ & $4 \cdot 7$ & $413 \pm 11$ \\
\hline $\begin{array}{l}\text { JET/3 } \\
\text { Dolerite } \\
\text { (whole-rock) }\end{array}$ & $1 \cdot 75$ & 0.363 & $4 \cdot 4$ & $314 \pm 9$ \\
\hline
\end{tabular}

